Peña-Vinces, JC. Casanova, L. Guillen, J. \& Urbano D (2016).International Competitiveness of Small and Medium-sized Enterprises: Peru, a Latin-American Emerging Market. Emerging Markets Finance and Trade. DOI: 10.1080/1540496X.2016.1156525 (In press).

\title{
International Competitiveness of Small and Medium-sized Enterprises: Peru, a Latin-American Emerging Market
}

\section{Author 1}

Jesús C. Peña-Vinces (Correspondence author)*

E-mail: jesuspvinces@us.es; College of Economics and Business, Department of Business Management and Marketing, University of Seville (Spain) Avenida Ramón y Cajal, s/n Sevilla (41018)-Spain.

Phone (+34) 954554438

\section{Author 2}

Lourdes Casanova, E-mail: Lourdes.casanova@cornell.edu; Samuel C. Johnson Graduate School of Management, Cornell University, Ithaca, NY,USA

\section{Author 3}

Jorge Guillen, E-mail: jguillen@esan.edu.pe; ESAN Graduate School of Business, Lima, Perú

\section{Author 4}

David Urbano, E-mail: david.urbano@uab.cat, Business Economics Department, Autonomous University of Barcelona, Barcelona SPAIN

*Correspondence author: College of Economics and Business, Department of Business Management and Marketing, University of Seville (Spain). E-mail: jesuspvinces@us.es, Phone: (0034) 954 554 438, Fax: (0034) 954 55 69 89, Av. Ramón y Cajal nº 1, 41018, Seville-Spain.

\begin{abstract}
Our research studies the international competitiveness of small and medium-sized enterprises (SMEs) in an emerging LatinAmerican country. Using a sample of 100 SMEs in Peru, we find that firms compete abroad with standardized products, which are conditioned by the host-country markets, human capital, and industry cooperation. However, the results show that the age and size of the firm are not determining factors in competing overseas. Our findings open a new agenda for policymakers when interpreting how they should promote and support Latin-American SMEs.
\end{abstract}

\section{Acknowledgments}

One of the authors (Dr. Peña-Vinces) would like to express his gratitude to Professor José L. Galán (University of Seville) because, without his valuable suggestions, this research would not have been possible. Furthermore, acknowledgment is due to the universities of South America, especially those of Peru (ESAN, UPC, UP, San Marcos, Wiener, etc.), and to the practitioners who provided the information in the surveys and interviews. Our sincere thanks go to those at the Samuel C. Johnson Graduate School of Management, Cornell University; without their hospitality, it would not have been possible to complete this research. Finally, special thanks to Professor Lourdes Casanova and Soumitra Dutta. 
Peña-Vinces, JC. Casanova, L. Guillen, J. \& Urbano D (2016).International Competitiveness of Small and Medium-sized Enterprises: Peru, a Latin-American Emerging Market. Emerging Markets Finance and Trade. DOI: 10.1080/1540496X.2016.1156525 (In press).

Keywords: SMEs, firm competitiveness, standardized products, industry cooperation, emerging country, local/international environment, Latin America, Peru.

\section{Introduction}

Many researchers have studied the international competitiveness of enterprises (Coviello et al. 1998; Cho et al. 2007; Elenurm 2007; Fahy 2002; Moon and Lee 2004). The vast majority of these studies have been carried out in highly industrialized countries (e.g., Japan, the USA, the UK, and Germany). However, very few studies have been conducted with a research focus on the economies of developing countries, such as those in Latin America. Numerous authors have suggested that research based on developed or highly industrialized countries cannot necessarily be applied to emerging countries (Cuervo-Cazurra et al. 2014; Peña-Vinces and Urbano 2014) as the economic situation of such countries is rather different, and many of them are undergoing consolidation (Casanova and Kassum 2014; Peña-Vinces et al. 2012; PeñaVinces and Delgado-Marquez 2013). There has been a recent increase in research considering multinational enterprises (MNEs) located in Latin America as a topic of study (Cuervo-Cazurra et al. 2014; Cuervo-Cazurra 2008; Peña-Vinces et al. 2012; Peña-Vinces and Delgado-Marquez 2013). Previous studies carried out with a focus on Latin America have addressed aspects related to modes of entry, natural markets, natural resources and value chains (Casanova 2004; Arze and Svensson 1997; Sánchez-Chiappe and Poratelli 2011; Peña-Vinces et al. 2012; Peña-Vinces and Delgado-Marquez 2013). However, such studies have not addressed the international competitiveness of small and medium-sized enterprises (SMEs). In other words, they have not depicted a holistic view of how Latin-American SMEs compete in foreign markets. As some authors have pointed out, there is limited information on Latin-American enterprises and it would be interesting to undertake further research in those emerging countries (Cuervo-Cazurra et al. 2014; Peña-Vinces and Delgado-Marquez 2013). Therefore, our study evaluates if the factors influencing the competitiveness of firms that operate from advanced economies are the same for the SMEs of an emerging market (Peru).

The significance of considering SMEs in Peru is that such companies operate in an identical environment to their LatinAmerican counterparts (e.g., Colombia, Peru, and Chile). The Peruvian business environment is chaotic and rather insecure from the perspective of foreign direct investment (FDI). A change in the political regime in many cases also implies an adjustment of the rules of the game for businesses, which are then translated to national industry, making it unstable to do business. Moreover, there is manifest corruption within public institutions in Peru. Informal businesses (e.g., run from home), defined as firms not registered in the public institutions of the state, are also a serious problem as they in effect account for 
Peña-Vinces, JC. Casanova, L. Guillen, J. \& Urbano D (2016).International Competitiveness of Small and Medium-sized Enterprises: Peru, a Latin-American Emerging Market. Emerging Markets Finance and Trade. DOI: 10.1080/1540496X.2016.1156525 (In press).

$72 \%$ of total industry (Díaz 2014). Terrorism in Peru persists, as indeed it does in Colombia. Furthermore, the sequestration of businesspersons is common in Peru.

Peru's exports are primarily based on raw materials, thus making it difficult for firms to obtain advantage from the effect of innovation in their supply chains. According to the World Bank's (2015) statistics, only around 15\% of total exports in the last decade were high-technology exports. This confirms that most Latin-American exports are of traditional products that are intensive in labor and the use of natural resources. Furthermore, some high-tech firms have serious difficulty finding qualified human capital. The characteristics described here are only a few examples the environment in which Peruvian SMEs operate; there are many more aspects, but they are not the subject of this study.

This study aims to contribute towards the theory of internationalization, helping to understand how Latin-American SMEs compete in world markets, in other words, the types of products (global/standardized) with which the firms of a LatinAmerican emerging market are competing abroad. Currently, Peru is reinforcing its position as an emerging market economy. According to the Bloomberg (2014) global emerging markets report, Peru was in seventh place out of the twentytwo top emerging markets in the world. To test our research model, we used a sample of 100 SMEs in Peru. The statistical analysis was carried out with partial least squares structural equation modeling methodology. Our study provides clear implications for both CEOs and governments, particularly in other Latin-American emerging economies, helping in the design of state public policy.

The paper is structured as follows: First, we set out our conceptual framework (Section 2) and provide a theoretical review of the factors that determine international competitiveness. Following this theoretical analysis, we develop our research hypotheses in the context of a Latin-American emerging country. Section 3 sets out the design of the survey and develops the measures of the research model. Finally, the results and conclusions are presented in Sections 4 and 5 respectively.

\section{Conceptual framework}

The concept of the international competitiveness of a firm refers to a company's ability to achieve more superior performance than its competitors in the global arena (Cerrato and Depperu 2011; Filatotchev et al. 2007) in terms of market share, increased exports and greater profit margins, which may result when firms do business overseas (Cerrato and Depperu 2011; Zeng et al. 2008). This also refers to the capacity and ability of a firm to produce goods and services to meet the requirements of foreign market (Cho et al. 2007; Peña-Vinces et al. 2012). From the environment perspective, firm competitiveness can be influenced by the country of origin and/or host country of the firm (Coviello et al. 1998; Moon and Lee 2004). From the industry perspective, the success of firms abroad depends on the success of the national industry, in other words, the industry collaboration between companies belonging to an industrial sector, or involved in similar activities 
Peña-Vinces, JC. Casanova, L. Guillen, J. \& Urbano D (2016).International Competitiveness of Small and Medium-sized Enterprises: Peru, a Latin-American Emerging Market. Emerging Markets Finance and Trade. DOI: 10.1080/1540496X.2016.1156525 (In press).

(e.g., textiles, agribusiness, chemicals, etc.) (Banerjee 2005; Birru 2011; Filatotchev et al. 2007). The resource-based view (RBV) considers that a firm's resources and capabilities and the way in which it exploits them explain its competitiveness abroad (Acedo and Jones 2007; Hatch and Dyer 2004). Not all companies have similar resources (i.e., firm size, skills of personnel, technology, etc.) (Fahy 2002; Peña-Vinces et al. 2012). Considering previous approaches, we analyze the factors that influence firm competitiveness in foreign markets.

\section{Global strategy}

The concept of a global strategy (GS) refers to a set of strategic attributes, such as integrated production, standardized products, and global marketing policies, that a firm establishes with the aim of improving its international competitiveness (Pla-Barber 2001; Peña-Vinces et al. 2014). Hence, one of the major decisions that companies must take is to decide which strategy they will use to compete efficiently and effectively in foreign markets. Companies move away from thinking of a strategy focused on a single country, or a particular culture. Firms try to orient all their processes toward competing on a global basis (Anwar 2003; Pla-Barber 2001; Rugman and Verbeke 1990). Therefore, in most markets they consider the global strategy on the basis of similarity so that their products and services only require small adaptations and can easily be identified (Pla-Barber 2001; Rugman and Verbeke 1990).

A review of the literature shows that firms drawing on a global strategy as a source of competitiveness are those that have been most successful in international markets (Anwar 2003; Elenurm 2007; Hitt et al. 2006; Knight and Kim 2009). Such firms may attempt to standardize the international tastes and preferences of their customers (Pla-Barber 2001; Rugman and Verbeke 1990). However, it is also the case that some multinationals do not need to adapt their global strategies to host markets when they sell abroad, as they only are interested in the distribution of their products (Subhash 1989).

The key to the success of a firm's global strategy is differentiation from its competitors (Anwar 2003; Hitt et al. 2006). Thus, companies need to possess in-depth knowledge of the sector and country in which these competitors operate (Subhash 1989). They should demonstrate an entrepreneurial culture with a strong global orientation (Hitt et al. 2006; Knight and Kim 2009). Simultaneously, firm success also depends on the characteristics of managers and their ability to conquer foreign markets (Anwar 2003; Hatch and Dyer 2004). On the other hand, working with global products could result in restrictions imposed by the legislations or regulations of the designated countries (Anwar 2003; Galán et al. 2007; Rugman and Verbeke 1990). As Pla-Barber (2001) notes, a firm's competitive position in a country is affected in great measure by its position in other countries and vice versa. Thus, firms tend to leverage their competitive advantages in most countries as quickly as possible. On the other hand, firms with foreign operations on a home-country basis seek to integrate their production activities in a single place (Mesquita and Lazzarini 2008) with the goal of standardizing their products. Nevertheless, difficulties arise when abrupt changes in markets occur (Galán et al. 2007). Therefore, in the context of an emerging-market firm, we propose the following hypothesis: 
Peña-Vinces, JC. Casanova, L. Guillen, J. \& Urbano D (2016).International Competitiveness of Small and Medium-sized Enterprises: Peru, a Latin-American Emerging Market. Emerging Markets Finance and Trade. DOI: 10.1080/1540496X.2016.1156525 (In press).

Hypothesis 1: Global strategy will positively influence the international competitiveness of SMEs from an emerging market.

\section{Human capital}

Human capital (HC) in our research is studied based on the set of specific characteristics of employees that help firms to obtain a competitive advantage in foreign markets (Acedo and Jones 2007; Chen and Lin 2006). The literature shows that some human capital characteristics, such as age, level of education (BA, Master's, $\mathrm{PhD}$ ), fluency in foreign languages, and knowledge and experience of foreign markets, have a positive impact on firms that sell worldwide (Acedo and Jones 2007; Pla-Barber 2001; Peña-Vinces et al. 2012). Such specific human capital characteristics are considered valuable and scarce resources (Acedo and Jones 2007; Hatch and Dyer 2004; Knight and Kim 2009; Wheeler et al. 2008). In this line, the possession of certain intangible assets, such as the knowledge and talent of employees, is a crucial element for improving the competitive position of firms in foreign markets (Cuervo-Cazurra et al. 2014; Hatch and Dyer 2004; Moen and Servais 2002). There is strong empirical evidence of this in Asia (Chen and Lin 2006; Cheng-Hua 2001; Jin and Moon 2006; Moon and Lee 2004) as well as in European firms. Thus, Acedo and Jones (2007), based on Pla-Barber's research (2001), found that the presence in international markets of those firms with the greatest representation is explained by the human capital characteristics previously described.

Some researchers consider that employees with experience, and contact with other countries and their cultures, drive the innovativeness and competitiveness of firms (Cuervo-Cazurra et al. 2014; Ferrier 2001; Porter 1998). Due to their business insights, particularly their global vision, these employees can spot new opportunities that others do not see (Hatch and Dyer 2004; Moen and Servais 2002). The current hyper-competition in international markets obliges firms to count on highly-qualified personnel (Peña-Vinces et al. 2014; Triguero-Sánchez et al. 2016). MNEs strive to sell their products worldwide, rather than concentrate their efforts on a single market (Peña-Vinces et al. 2014). This means they distribute standardized products (Pla-Barber 2001), in turn forcing them to hire either directly or indirectly personnel with certain characteristics. Therefore, many MNEs see international markets as the only option (Peña-Vinces and Urbano 2014; PeñaVinces et al. 2014). This implies having a profound understanding of the needs and demands of foreign markets (Knight and Kim 2009; Zeng et al. 2008; Subhash 1989). It is specifically the skills of their staff that enables companies to produce standard products that are then accepted in global markets (Leonidou et al. 1998; Theodosiou and Leonidou 2003). Therefore, the literature review allows us to establish the following hypotheses:

Hypothesis 2: Human capital will positively influence the international competitiveness of SMEs from an emerging market.

Hypothesis 3: Human capital will positively affect the global strategy of SMEs from an emerging market.

\section{Firm size}


Peña-Vinces, JC. Casanova, L. Guillen, J. \& Urbano D (2016).International Competitiveness of Small and Medium-sized Enterprises: Peru, a Latin-American Emerging Market. Emerging Markets Finance and Trade. DOI: 10.1080/1540496X.2016.1156525 (In press).

Commonly, most studies have used firm size (FS) as a control variable, rather than as a factor of competitiveness (Acedo and Jones 2007; Chen and Lin 2006). However, many other studies have shown that firm size is a decisive factor in competing in foreign markets (Ito and Pucik 1993; Moon and Lee 2004; Nadvi 1999; Wu and Pangarkar 2006). Although Bonaccorsi (1992) found that firm size is not a determining factor of foreign activities, other research has concluded that it has a positive effect on the firm's international activities (Cuervo-Cazurra 2008; Wheeler et al. 2008; Zou and Stan 1998; Zeng et al. 2008). This is because large firms can exploit economies of scale, research, and the actions related to international marketing (Cuervo-Cazurra 2008; Wu and Pangarkar 2006). In other words, they use their size (large) to reduce costs (Ito and Pucik; 1993; Zeng et al. 2008; Peña-Vinces and Urbano 2014). Large firms also have the capacity to create and produce products on a large scale (Ito and Pucik; 1993; Zeng et al. 2008). As such, firm size will condition its demand abroad (Nadvi 1999; Wu and Pangarkar 2006). Also large firms are better placed to face competitor reactions because they have access to more capital to acquire new technologies or invest in research and development (Cuervo-Cazurra 2008; Zeng et al. 2008). In this way, they can also homogenize their production (Subhash 1989). However, precisely due to their size (large), such firms are often rendered inflexible (Elenurm 2007), as their ability to respond to the market slows down considerably (Cuervo-Cazurra 2008; Wu and Pangarkar 2006). Taking into account that our study is focused on SMEs, we pose the following hypothesis:

Hypothesis 4: Firm size will positively influence the international competitiveness of the SMEs from an emerging market.

\section{Firm age}

Firm age (FA) refers to the length of time that a company has been operating in the markets (Wheeler et al. 2008; Zou and Stan 1998). In the case of international markets, there is also the time spent working abroad (Cuervo-Cazurra 2008; PeñaVinces and Urbano 2014). Time has traditionally been associated with knowledge, and this in turn with competitiveness. However, Moen and Servais (2002) demonstrated in their study of the "born global firm" that a greater number of years of operations in international markets is not a decisive factor in international competitiveness as these companies have been internationally competitive from their inception (Oviatt and McDougall 1994). This is in accordance with the international business perspective (Acedo and Jones 2007; Oviatt and McDougall 1994; Knight and Kim 2009). In contrast, the industrial economics perspective, specifically, the "Flying Geese theory" (Chen and Lin 2006; Kasahara 2004), indicates that firms must prepare locally in their home country for a certain period prior to moving abroad to compete in international markets. If they do not do so, their survival will be put at risk. On the other hand, some research (Cuervo-Cazurra 2008) continues to support the idea that firm age plays a significant role. This is the case of Latin-American multinational companies from emergent economies, such as Brazil and Chile (Arze and Svensson 1997; Mesquita and Lazzarini 2008). Taking into account the born global firm approach (fewer years of operations), we propose the following hypothesis.

\section{Hypothesis 5: Firm age will negatively influence the international competitiveness of SMEs from an emerging}


Peña-Vinces, JC. Casanova, L. Guillen, J. \& Urbano D (2016).International Competitiveness of Small and Medium-sized Enterprises: Peru, a Latin-American Emerging Market. Emerging Markets Finance and Trade. DOI: 10.1080/1540496X.2016.1156525 (In press).

market.

\section{Collaboration in the industrial sector}

Sector and/or industry are widely used as control variables. However, for the purposes of this research, we include industry collaboration between companies belonging to an industrial sector or involved in similar activities (e.g., textiles, agribusiness, chemicals, etc.). In isolation, industry would only indicate a firm's position within an industrial group, but not the role that played in its competitiveness. Industry collaboration, on the other hand, refers to the mechanisms that allow firms -in one way or another - to compete more successfully in foreign markets (Banerjee 2005; Birru 2011; Filatotchev et al. 2007). Firms need the support and assistance of other companies to be able to grow and compete internationally (Arze and Svensson 1997; Cho et al. 2007; Nadvi 1999). Industry collaboration among firms can be vertical and/or horizontal. Vertical collaboration involves companies at different stages of a value chain (producers and customers), whereas horizontal collaboration occurs between companies at the same point in a value chain (often competitors) (Birru 2012). Therefore, the ability of an SME to become a participant in the global production chain depends on its own capacity (Filatotchev et al. 2007) to overcome the constraints of its size and immaturity, and continuously innovate productively as it grows (Guerrieri and Pietrobelli 2004; Yuhua and Bayhaqi 2013).

Empirical evidence shows that firms located in a highly competitive industry benefit from research and development activities (Banerjee 2005; Cheng-Hua 2011), and such firms belong to sectors with similar characteristics and they tend to be more competitive globally (Nadvi 1999; Mesquita and Lazzarini 2008). Furthermore, industry cooperation allows SMEs, illinformed in terms of foreign markets, to achieve internationalization as a result of the support of other companies (Filatotchev et al. 2007; Nadvi 1999; Zeng et al. 2008). Therefore, for the Latin-American emerging market context, we propose the following hypotheses:

Hypothesis 6: Industry collaboration will positively influence the SMEs 'international competitiveness.

Hypothesis 7: Industry collaboration will positively influence the global strategy of SMEs.

\section{The environment of the host country}

A firm's international competitiveness is closely linked to the nation of origin and the host country of enterprises. Therefore, all the competitive actions of an enterprise will always be conditioned by the environment of the host country (i.e., macroeconomics and microeconomics) in which firms carry out their business operations (Elenurm 2007; Ferrier 2001; Nadvi 1999; Wheeler et al. 2008). This means that the firm's strategies will be constrained by macroeconomic policies practiced in foreign countries (Galán et al. 2007; Toppinen et al. 2007). The literature on MNEs shows that understanding socio-cultural variables (culture, language, religion, attitudes, customs, design, education level, and race) is vital in competing globally (Hofstede 1993; Galán et al. 2007). These variables will affect the strategy developed by companies and may influence-positively or negatively - their competitiveness (Hofstede 1993; Pla-Barber 2001; Wheeler et al. 2008; Zou et al. 1997). The evidence provides numerous cases of both the success and failure of enterprises where socio-cultural variables 
Peña-Vinces, JC. Casanova, L. Guillen, J. \& Urbano D (2016).International Competitiveness of Small and Medium-sized Enterprises: Peru, a Latin-American Emerging Market. Emerging Markets Finance and Trade. DOI: 10.1080/1540496X.2016.1156525 (In press).

have played a significant role in the firms' competitiveness (Jin and Moon 2006; Nadvi 1999; Toppinen et al. 2007). The truth is that the environment of the host country will in one way or another require enterprises to adjust their business strategy in accordance with the type of socio-cultural characteristics of each international consumer (Anwar 2002; Galán et al. 2007; Hofstede 1993; Jin and Moon 2006). Despite the many factors that may be found in the literature, they can be summarized into three groups: i) factors related to the foreign market, linked to the growth in demand of foreign markets; ii) factors associated with political and legal aspects of the destination of the products and services of domestic firms; iii) social and cultural factors (Galán et al. 2007; Rugman and Verbeke 1990; Wheeler et al. 2008). The approaches prevalent in the literature lead us to propose the following hypothesis:

Hypothesis 8: The environment of the host country will positively influence the global strategy of SMEs.

Having developed our research model as shown in Figure 1, we demonstrate the proposal for evaluating the hypotheses in the following section.

\section{Methodology}

\section{[Insert Figure 1 about here]}

\section{Population and sample description}

In the last decade, many Latin-American economies have attained emerging status, as in the case of Brazil, Chile, Colombia, and Peru (Bloomberg 2014; World Bank 2015). These countries have similar economic characteristics (Bloomberg 2014). Therefore, a study of SMEs based on Peru could provide conclusions and implications useful to other South American economies (e.g., Chile, Colombia, and Ecuador). In 2014, Peru was the second exporter of high-tech products among all Latin-American economies, Brazil being in first place (World Bank 2015). Moreover, Peru also was the first country to experience a greater volume of exportation over the period 2009-2013 (World Bank 2015), according to the Latin American Index of Industrial Production of the Inter-American Development Bank (2010) [this index evaluates the rate of growth of national industry within Latin-American economies]. In 2010, Peru was ranked one of the highest countries in the region, with a rate of growth of industrial production of $240.60 \%$. Brazil, the most competitive economy of Latin America (CastroGonzáles et al. 2016) only had a rate of industrial growth of $165.89 \%$, Chile 179.88\%, Colombia, 147.79, and Ecuador 144.40. In 2014, Peru continued to lead the ranking of industrial growth in the South American region, with a rate of 271.81\%. Brazil, the biggest economy of South America, only had a rate of $160.71 \%$ and Chile $197.12 \%$, the remainder of Latin-American countries showing similar rates of industrial growth. This indicates that Peru continues to lead in terms of growth in national industry, which means that the industry of Peru serves as a model to study firm competitiveness. Until 2010, when we finished our research, Peru was the economy exhibiting better growth in exports of goods and services as a percentage of GDP (Inter-American Development Bank 2015) than other economies. Likewise, in the period 2005-2010, 
Peña-Vinces, JC. Casanova, L. Guillen, J. \& Urbano D (2016).International Competitiveness of Small and Medium-sized Enterprises: Peru, a Latin-American Emerging Market. Emerging Markets Finance and Trade. DOI: 10.1080/1540496X.2016.1156525 (In press).

Peru had a mean rate of growth of $5.5 \%$ of its GDP (World Bank, 2015). Thus, Peru is one of most of the significant economies of South America.

Based on the above consideration, we studied the SMEs of Peru according to the classification of the Ministry of Tourism and Commerce (Mincetur in the Spanish acronym). The SMEs fall within the 12 most important industrial sectors of the country. Table 1 shows the characteristics of the firms represented in the study.

Concerning the methodology, we sent questionnaires to the SMEs ranked in the top 1,000 firms (Mincetur 2006). For inclusion, it was necessary that all the enterprises should have the same characteristics. The most significant are as follows: a period of operation in foreign markets of at least five years; international sales comprising at least $60 \%$ of total sales; information available on turnover to categorize firms as SMEs (European Commission 2005); operating in at least five countries other than the country origin.

With respect to the unit sample, responses to the questionnaires (distributed via email and postal mail) were sought from the international operations managers. To ensure that the respondents were the same persons as those identified in the questionnaires distributed via email, first we contacted them by telephone to undertake brief interviews, and then we quickly sent an email to their corporate email to thank them for their participation. Finally, the emails were checked to corroborate if the respondent was the same person contacted previously. For the postal mail questionnaires, we sent envelopes by hand to personal addressees ensuring the personal identification of those who participated in the survey

A total of 100 questionnaires (discounting those that were incomplete) were returned via email (80\%) and postal mail (20\%) in the period June 2007 to May 2009, representing a response rate of 10.3\%. The low response rate is explained in part by the fact that many SMEs in developing countries are hesitant about completing surveys from foreign universities (PeñaVinces et al. 2012). Another possible explanation might be the duration of the study, taking into account that the time from establishing initial communication with the firms to completion of the data collection was more than six months. During this period, many managers changed jobs, making it impossible to re-contact with them a second time, particularly as the first telephone call was made to the managers in person. Another difficulty was the lack of information on updates concerning the firm's address because many postal surveys were returned. Finally, many managers did not get authorization from their enterprises to participate in our research.

In international business research, particularly when one is working with small firms, often involving a single company or informant, there are difficulties in obtaining multiple participants (Aragón-Correa et al. 2008; Peña-Vinces and Urbano 2014; Triguero-Sánchez et al. 2016; ). As a result, it might be possible to find potential biases in the mono-method (Chang et al. 2010; Doty and Glick 1998; Podsakoff et al. 2003; Kamakura 2010). However, there are several statistical remedies to detect and control for any possible common method variance (CMV). A post hoc Harman one-factor analysis is often used to check whether the variation in the data can be mainly attributed to a single factor (Chang et al. 2010; Podsakoff et al. 
Peña-Vinces, JC. Casanova, L. Guillen, J. \& Urbano D (2016).International Competitiveness of Small and Medium-sized Enterprises: Peru, a Latin-American Emerging Market. Emerging Markets Finance and Trade. DOI: 10.1080/1540496X.2016.1156525 (In press).

2003). Additionally, other statistical procedures can be applied to partial out common factors or to control for them. (Chang et al. 2010; Doty and Glick, 1998; Podsakoff et al. 2003; Kamakura 2010).To avoid CMV problem, we undertook the following steps: (i) We promised the managers that our analysis would be aggregated and no organization would be identified individually. (ii) We identified highly qualified respondents (e.g., international operations managers). The extant literature suggests that the views of a single and well-qualified informant will capture a firm's approach better than the opinions of several respondents, especially when decisions are centralized (Aragón-Correa et al. 2008; Peña-Vinces and Urbano 2014; Triguero-Sánchez et al. 2016). (iii) Following Podsakoff et al. 2003 and Podsakoff and Organ’s (1986) recommendations, we improved the reliability of our data by conducting an exploratory principal components analysis with varimax rotation. Our results confirmed the absence of a single factor that accounted for most of the covariances in our variables, suggesting the absence of CMV. In the Kaiser-Meyer-Olkin (KMO) test and Bartlett's test of sphericity $(\chi 2)$, both offered satisfactory levels (see the results in Table 2).

Also, we must indicate that the 100 SMEs included in December 2014 were evaluated again to check if they continued selling abroad. The qualitative information revealed that $98 \%$ continued operating in international markets. On the other hand, we emphasize that Peruvian SMEs exhibit a small drop in their sales, which can be explained in part by the world economic crisis, taking into account that the US and European countries were their principal markets. With regard to the qualitative analysis of the sample, the average age of the companies is 24 years for total operations and 14 years for international transactions (i.e., only exporting), and a maximum of 554 employees (mean 238). The vast majority of the companies sold their products to more than 12 countries (e.g., the US, China, Switzerland, Germany, Spain, etc.). This figure reflects the ability of a firm to compete and sustain a presence in international markets (Cerrato and Depperu 2011). In terms of the international sales of the companies, the mean rate of exporting was US\$15,600,746 in free on board (FOB) sales. Thus, it is also important to bear in mind the concept of an SME, which is "any entity engaged in economic activity, irrespective of its legal form (private or public).” Small enterprises are defined as enterprises that employ fewer than 50 persons and the annual turnover or annual balance sheet total of which does not exceed 10 million euros (European Commission 2005). In the international arena, SMEs are firms that have a share of foreign trade, but also have different kinds of operations worldwide, such as production facilities, research and development (R\&D) activities, and technical assistance services (European Commission 2005). Therefore, the European Commission's (2005) criteria of sales $>€ 50$ million would allow the classification of Peruvian SMEs as medium-sized enterprises (see Table 1).

\section{[Insert Table 1 about here]}

\section{Measures}


Peña-Vinces, JC. Casanova, L. Guillen, J. \& Urbano D (2016).International Competitiveness of Small and Medium-sized Enterprises: Peru, a Latin-American Emerging Market. Emerging Markets Finance and Trade. DOI: 10.1080/1540496X.2016.1156525 (In press).

To measure firms' international competitiveness, we have used the measures developed by Zou and Stan (1998), revalidated by Wheeler et al. (2008): a) percentage of local profits/total profits; b) percentage of foreign profits/total profits.

Simultaneously, following Cerrato and Depperu's (2011) recommendations, to calculate this construct we also employed more subjective measures related to the perception of objectives and goals achieved in foreign markets, and the perception of success in the international market. It is also important to mention that Peña-Vincent et al. (2012) tested such measures within the Latin-American context (see items in Table 2). We have to say that to develop the above-mentioned measures of competitiveness - (a) and (b) - it was necessary to review the websites of both the National Customs Authority of Peru (SUNAT in the Spanish acronym) and the Ministry of Tourism and Commerce (Mincetur). The first website collects financial and general accounting information, such as the number of employees, year of foundation, etc. The second website shows information on foreign sales, such as the destination market of products, types of products, volume of exportation, prices, etc.

The measurement utilized by Pla-Barber (2001) was applied to evaluate the global strategy. The respondents had to give an evaluation based on a seven-point scale, ranging from disagreeing (1) to agree (7). This construct considered aspects of the firms such as the standardization of consumers' needs in all markets, the same product offering worldwide, the standardization of technology for all markets, and the standardization of marketing policies worldwide.

To measure the human capital characteristics construct, following Acedo and Jones (2007, p. 242), a seven-point scale (1=not at all important, $7=$ absolutely important $)$ was used. This construct included six items evaluating business success in foreign markets in relation to the importance of human capital, evaluating aspects of the employees such as their age and education, fluency in foreign languages, experience in foreign markets, etc.

In line with the literature reviewed, firm size was assessed by the number of employees (the mean of the last three years) (Acedo and Jones 2007; Arze and Svensson 1997; Buckley et al. 1990; Ito and Pucik 1993; Mesquita and Lazzarini 2008; Wu and Pangarkar 2006). For firm age, two items of measurement were used, one referring to the number of years of operating in the local markets of the country of origin of the firm (Moen and Servais 2002; Wheeler et al. 2008), and the other concerning the number of years engaged in exporting.

As mentioned above, the environment of the host country involves the target markets of the products of international companies. Here, we used a reduced version of a seven-point scale developed by Galán et al. (2007), comprising only six items with similar characteristics. This measured aspects of the business, such as factors related to the growth of demand in foreign markets, those associated with political and legal aspects, and the social and cultural factors of the destination markets.

The collaboration of the industrial sector was considered as a second-order factor (Chin and Frye, 1998). Consequently, we mapped two first-order factors or dimensions, i.e., sector cooperation (SC) and networking (networking), 
Peña-Vinces, JC. Casanova, L. Guillen, J. \& Urbano D (2016).International Competitiveness of Small and Medium-sized Enterprises: Peru, a Latin-American Emerging Market. Emerging Markets Finance and Trade. DOI: 10.1080/1540496X.2016.1156525 (In press).

with respect to this higher-level construct. Hence, to measure the sector cooperation dimension, the survey questions developed by Belso-Martinez (2006, p. 217) were used with a seven-point Likert scale to assess the level of importance for firms ( $1=$ not at all important, $7=$ absolutely important), where aspects such as the relationship with the client's relevance in internationalization, the presence of suppliers abroad, relations with the competitor's relevance in the internationalization process, etc. are evaluated. In the case of the networking dimension, following the arguments of Lin and Chaney (2007), who stated that the presence in foreign markets is due to the collaboration of networks, two measurement items developed by these authors were used (see Table 2).

\section{Hypothesis testing}

Data analysis was conducted using structural equation modeling partial least squares (SEM-PLS) methodology (Chin and Frye 1998), evaluating the SEM-PLS in two stages. First, the measurement model was assessed. In the second phase, the structural model was estimated (Hair et al. 2011). The SEM-PLS procedure has gained interest and been used by researchers in recent years because of its ability to model latent constructs under conditions of non-normality and with small to medium-sized samples (Chin 1998; Hair et al. 2011; Marcoulides and Saunders 2006). For this reason, we chose this particular statistical technique. Our research investigation is composed of seven constructs; two of these are formative, and therefore it is necessary to differentiate between reflective and formative constructs as both constructs require different statistical treatments (Chin and Frye 1998; Hair et al. 2011).

\section{Formative constructs}

With formative measures, the first step is to ensure content validity, that is, the extent to which the elements of a measurement procedure are relevant and representative of the construct that they will be used to measure (Buysse et al. 1989; Hair et al. 2011; Haynes et al. 1995). Establishing content validity is a necessarily initial task in the construction of a new measurement procedure (Haynes et al. 1995). However, the validity (e.g., construct validity) and reliability (e.g., internal consistency) of the content (i.e., elements) selected should be tested before an assessment of content validity can be made (Hair et al. 2013; Haynes et al. 1995). Formative constructs are based on the assumption that the indicators cause the construct (Hair et al. 2011). An important characteristic of the formative indicators (FIs) is that they are not interchangeable, as is true with reflective indicators. Thus, each indicator of a formative construct captures a particular aspect of the construct's domain. As a consequence, the breadth of coverage of the construct domain is crucial to ensure that the domain of content of the focal construct is adequately captured (Hair et al. 2011). As there is no "common cause" for the items in the construct, there is no requirement for the items to be correlated, and they may be entirely independent. In fact, collinearity among formative indicators can present significant problems because the weights linking the formative indicators to the construct can become unstable and non-significant (Hair et al. 2011). Furthermore, the formative indicators have no individual measurement error terms. That is, they are assumed to be error-free in a conventional sense (Hair et al. 2013). Hair et al. (2011, p. 17) established 
Peña-Vinces, JC. Casanova, L. Guillen, J. \& Urbano D (2016).International Competitiveness of Small and Medium-sized Enterprises: Peru, a Latin-American Emerging Market. Emerging Markets Finance and Trade. DOI: 10.1080/1540496X.2016.1156525 (In press).

that when a PLS-SEM presents formative constructs, attention must be paid to three key issues: (a)The indicators' relative contribution to the construct (report indicator weights). (b)The significance of weights (t-values, p-values or standard errors). (c) The VIF multicollinearity $<5 /$ tolerance $>0.20$ and/ or condition index $<30$.

The results of these evaluations can be seen in Table 2. We can observe the weights, the t-values, and the variance inflation factor (VIF). In the case of the VIF analysis, we decided to opt for the rule of thumb suggested by Roberts and Thatcher (2009, p. 18). They say a formative construct does not present problems of multicollinearity if any of its indicators record values less than or equal to 3.30. Following this rule, no items show a problem of multicollinearity (see Table 2). We highlight that the tests of multicollinearity were performed using the SPSS 20 program.

\section{Reflective constructs}

The evaluation of a measurement model begins with the assessment of individual item reliability (Marcoulides and Saunders 2006). SEM-PLS procedure establishes that each item's measurement must exceed a threshold of 0.70; however, in exploratory studies like this, 0.40 is an acceptable value (Hair et al. 2011). In our study, three items of the construct industry did not exceed the necessary parameters; therefore, these items were deleted (see Table 2). The next step is to estimate the composite reliability (CR). The reflective constructs have recorded values above the limit set (Nunnally 1997; CR $\geq 0.70$ ). Finally, the average variance extracted (AVE) and the discriminant validity (DV) are evaluated. To accept AVE, the value must exceed 0.50 (Hair et al. 2011). The five reflective constructs show values above the parameter set. For the DV analysis, the square root of the AVE is calculated (see Table 3). Once the validity and reliability of the measurement model have been demonstrated, the structural model is assessed (Chin and Frye, 1998; Marcoulides and Saunders 2006). The structural model was tested by measuring the intensity of path coefficients or standardized regression weights and the explained variance $\left(\mathrm{R}^{2}\right)$ of the endogenous or dependent variables. Furthermore, the nonparametric bootstrapping technique (re-sampling procedure of 5,000 samples) was applied to evaluate the accuracy and stability of the estimates obtained(Chin and Frye, 1998). In addition, the predictive relevance was evaluated through $\mathrm{Q}^{2}$ (Hair et al. 2011); this exceeded the requirement of $\mathrm{Q}^{2}$ greater than zero $\left(\mathrm{Q}^{2}>0.00\right)$. Finally, the results confirm that the structural model has predictive quality, obtaining a goodness-of-fit (GOF) close to one (Hair et al. 2011) (see Figure 2).

\section{[Insert Figure 2 about here] and [Insert Tables 2 and 3 about here]}

\section{Analysis of results}

Our international competitiveness model only attempts to test the theory of developed economies in an emerging market context. The findings are consistent with the literature review. Thus, Hypothesis 1 is confirmed $\left(\mathrm{H}_{1}, B_{0}: 0.364^{* *}\right)$ in that firm competitiveness abroad depends on its global orientation (global strategy); in other words, SMEs perceive the foreign market as single (see Table 4 and Figure 2), which is coherent with the literature reviewed (Anwar 2003; Elenurm 2007; Hitt et al. 2006; Knight and Kim 2009; Wu and Pangarkar 2006). We can see how the use of a global strategy compared to a strategy 
Peña-Vinces, JC. Casanova, L. Guillen, J. \& Urbano D (2016).International Competitiveness of Small and Medium-sized Enterprises: Peru, a Latin-American Emerging Market. Emerging Markets Finance and Trade. DOI: 10.1080/1540496X.2016.1156525 (In press).

of diversification and adaptation to national markets is preferred by the SMEs in a Latin-American emerging country (Peru). Therefore, SMEs compete internationally with standardized products, which need to understand fully the nature and demands of foreign markets to unify them (Pla-Barber 2001; Subhash 1989). Hypothesis 2 concerns the evaluation of the effects of specific human capital characteristics on firm competitiveness. This construct does not show statistical significance $\left(\mathrm{H}_{2} ; \beta=0.012\right)$. It seems appropriate to go deeper into this relationship through future lines of research to explain why they have no influence in an emerging context. However, we offer one explanation: it could be that SMEs may not exploit this resource (human capital) fully in comparison to large firms (Buckley et al. 1990; Galán et al. 2007; Hatch and Dyer 2004; Knight and Kim 2009). Hypothesis 3 relates to human capital concerning the firm's global orientation (global strategy). The results show a positive effect, and in line with the RBV (Acedo and Jones 2007; Chen and Lin 2006; Triguero-Sánchez et al 2016), this type of resource in an SME is noted as being valuable and necessary to compete in foreign markets. Moreover, it becomes a competitive advantage, stressing the importance of certain resources and capabilities to compete in a global environment (Cuervo-Cazurra 2008; Fahy 2002; Knight and Kim 2009). Hypotheses 4 and 5 are not supported by the results. On the one hand, firm size does not show statistical significance $\left(\mathrm{H}_{4} ; \beta=0.124\right)$. On the other hand, firm age $\left(\mathrm{H}_{5} ; \beta=\right.$ -0.261) does not show a positive effect on the SMEs' competitiveness, which contradicts the values expected. However, we highlight its tendency. Thus, firm age might indicate that fewer years operating in the domestic market positively contributes to the competitiveness of SMEs. These findings allow us to consider the Peruvian SMEs as "born global firms," as Rialp et al. (2005) proposed. That is, Peruvian SMEs have without doubt a defined international orientation. Firm size indicates that SMEs, by virtue of their size, enjoy greater possibilities of competing in foreign markets in comparison to large enterprises (Sánchez-Chiappe and Poratelli 2011) as Peruvian SMEs could be considerably more flexible than large companies when they operate worldwide (Peña-Vinces et al. 2012). Hypothesis 6 concerns the role the collaboration of the industrial sector plays in firm competitiveness in foreign markets. Our results show positive effects $\left(\mathrm{H}_{6} ; \beta=0.382^{* *}\right)$, reinforcing the approach of industrial economics regarding industry cooperation (Banerjee 2005; Barge-Gil and Modrego 2011; Birru 2011; Cheng-Hua 2011; Lin and Chaney 2007; Porter 1990). Therefore, the collaboration of the industrial sector is crucial because it allows SMEs to grow and compete, and achieve their internationalization centered on a network approach (Belso-Martínez 2006; D'Cruz and Rugman 1993; Chen and Lin 2006; Mesquita and Lazzarini 2008). Furthermore, it allows companies to focus on certain activities in the industry value chain, and achieve the competitiveness needed to survive and remain in international markets (Nadvi 1999; Sánchez-Chiappe and Poratelli 2011). Hypothesis 7 is related to industry cooperation regarding the global approach of the firm (e.g., global strategy). The results reveal that cooperation between firms is essential as they help with the internationalization of global production (Banerjee 2005; Barge-Gil and Modrego 2011; Birru 2011; Cheng-Hua 2011). Hence, it is also interesting to observe how the collaboration of the industrial sector (see Figure 2) plays a very important role in the use of the global strategy and contributes $9.8 \%$ to explaining the variance of this factor in 
Peña-Vinces, JC. Casanova, L. Guillen, J. \& Urbano D (2016).International Competitiveness of Small and Medium-sized Enterprises: Peru, a Latin-American Emerging Market. Emerging Markets Finance and Trade. DOI: 10.1080/1540496X.2016.1156525 (In press). competitiveness $\left(\mathrm{R}^{2}=0.260\right)$. In the same line, Hypothesis 8 concerns the effect of the international environment on the firm's global orientation (GS). We observe that foreign markets exert a positive influence on the firm's orientation $\left(\mathrm{H}_{8}, \beta=\right.$ 0.202*). This is consistent with the traditional literature on international business (Cuervo-Cazurra 2008; Galán et al. 2007; Leonidou et al. 1998; Theodosiou and Leonidou 2003), which reminds us of the need to analyze the destination markets before moving out to compete globally. Thus, this hypothesis coincides with the qualitative information of the sample, revealing that more than $60 \%$ of sales of the Peruvian SMEs go to foreign markets.

\section{[Insert Table 5 about here]}

\section{Conclusions and implications}

The main conclusion that can be drawn from the different analyses performed is the fundamental role of having a global strategy. In other words, this is the primary determinant of international competitiveness or also, if one wishes, of the competitive advantage of SMEs. As our results show, the Peruvian SMEs utilize a global strategy to compete overseas instead of relying on a strategy of differentiation and national adaptation. We must therefore note what determines the adoption of this type of strategy. We can confirm that the environment of the host countries of SMEs (i.e., the factors of destination markets) in which they operate is one of the most favorable factors for the standardization of their products. That is, the host market size, the growth rate of foreign demand, international trade agreements, political stability, and social and cultural factors (such as race, income, consumption habits, religion, etc.) are the issues that allow Peruvian SMEs to exploit their global strategy.

Based on the existence of a global strategy within Peruvian SMEs, their operations in international markets would not be possible without the collaboration of the industrial sectors. This coincides with the results of a vast number of investigations carried out within industrialized countries (Galán et al. 2007; Nadvi 1999; Porter 1998; Belso-Martinez 2006). That is, the functioning of a global strategy in SMEs depends on the collaboration of its suppliers: those of raw materials, finance and insurance, international transportation, and qualified staff, etc., and at the same time, of the organizational networks (Barge-Gil and Modrego 2011; Cheng-Hua 2011; D'Cruz and Rugman 1993; Mesquita and Lazzarini 2008) or the cooperative agreements that SMEs maintain, either with sales or for the acquisition and transfer of knowledge. These are factors that also enable them to reduce their costs and enhance their internationalization. Here, the collaboration between SMEs is conditioned by local customers and competitors as the latter contribute to the creation of new knowledge (Chen and Lin 2006; Porter 1998).

On the other hand, we believe that the companies have been able to bear fruit from their global strategy in foreign markets owing to a major source of competitive advantage, such as the human capital or staff working within the Peruvian SMEs. In our case, we can observe that they have a high level of academic preparation, such as having degrees at Master's 
Peña-Vinces, JC. Casanova, L. Guillen, J. \& Urbano D (2016).International Competitiveness of Small and Medium-sized Enterprises: Peru, a Latin-American Emerging Market. Emerging Markets Finance and Trade. DOI: 10.1080/1540496X.2016.1156525 (In press).

level (MBAs) and even $\mathrm{PhDs}$, and in addition the knowledge of various languages and of foreign markets through traveling for business or tourism. Simultaneously, such particular characteristics make SMEs from emerging markets aware of their global reality, and their possibilities of opting for standardization rather than a differentiation strategy in international markets.

As noted above, global strategy is the primary determinant of the international competitiveness of SMEs located in a Latin-American emerging country, such as Peru, for small enterprises relying on the adaptation of their national products to destination markets. Hence, their function and design are not found in the hands of a single person but rather in good staff who possess the characteristics described above. In this regard, the staff working in Peruvian SMEs are conscious of their weaknesses in terms of competing abroad with an international strategy of national diversification. Therefore, it is evident that such firms (Peruvian SMEs) have a clearly defined niche market (standardized products).

Nevertheless, when human capital is analyzed in relation to firm competitiveness $\left(\mathrm{H}_{2}\right)$, our results show that the characteristics discussed above do not have a significant effect. We can underline their positive trend although it is slight. One possible explanation is that in some Latin-American countries (i.e., Peru) the possession of certificates (BA, MBA, Ph.D.) is not necessarily synonymous with the presence of globally-qualified staff in the firm; it may purely be a requirement either to change status or obtain incentives that employees receive when they have completed higher education. It could also confirm, through the absence of Peruvian universities in the world ranking, lower competitiveness in terms of research (Peña-Vinces and Urbano 2014).

As we have pointed out previously, Peruvian SMEs compete mainly in the international arena through standardized products; several researchers (Subhash 1989; Zou et al. 1997) have argued that this occurs as the products of these companies always or almost always go to mature target markets (i.e., supermarkets and large retail chains), where the acceptance of homogenized products is much easier. This means the Peruvian SMEs only compete with commoditized sectors. For instance, we can find in the USA products manufactured by Peruvian SMEs (e.g., asparagus, coffee, legumes, sugars, chocolate, juices, drinks, perfumes, shirts, pants, underwear, blankets, etc.), which are essentially the same as those found in other markets (Europe and Asia), but with minute differences such as in the language of the label, which is adapted for each country or group of countries.

Regarding firm age, our results suggest that fewer years of operation in local markets gives SMEs greater possibilities of success in foreign markets (the firm's competitiveness). That is to say, SMEs have not had an extended period of preparation prior to competing internationally.

The literature reviewed indicated that government efforts in industrialized countries are crucial for the success of SMEs in their entrance into foreign markets (Cheng-Hua 2011). However, the descriptive information revealed that $80 \%$ of the SMEs surveyed considered that the actions taken by governments have not promoted their success in foreign markets. Thus, we can say that the governments do not necessarily play a significant role in international competitiveness. This has also been 
Peña-Vinces, JC. Casanova, L. Guillen, J. \& Urbano D (2016).International Competitiveness of Small and Medium-sized Enterprises: Peru, a Latin-American Emerging Market. Emerging Markets Finance and Trade. DOI: 10.1080/1540496X.2016.1156525 (In press).

found in a study of an SME located in an African developing country, Nigeria (Abereijo et al. 2009). Thus, we suggest that policymakers bear the responsibility for the design of policies that promote international activities. SMEs should be considered more seriously as they are the main generators of the economic development of countries, and consequently foster the progress of underdeveloped countries through job creation (Peña-Vinces 2009).

Finally, the results obtained show a certain degree of coincidence with the theoretical background (economic and international theories) posed in the study. These suggest the need for the use of a global approach as not all theoretical knowledge from industrialized countries has shown significant importance for the competitiveness of Latin-American (Peruvian) SMEs in an emerging context $\left(\mathrm{H}_{2}, \mathrm{H}_{4}\right.$, and $\mathrm{H}_{5}$ not being significant).

One of the main limitations of the study is the cross-sectional nature of the research. Likewise, the authors also acknowledge that there are other variables that could equally influence the firm's international competitiveness, but which for reasons of the extension of the questionnaire are not included. Therefore, our research model might be improved by incorporating other variables, such as international marketing strategy, research and development, and other aspects that might also influence firm competitiveness. Our PLS model did not evaluate the possible problem of endogeneity, which refers to the causal modeling assumption that the independent variables in an equation are uncorrelated with the error term (McIntosh et al. 2014). Unfortunately, endogeneity tends to be the rule rather than the exception in applications of multiple regression and related methods when using observational rather than experimental data (Antonakis et al. 2014; Semadeni et al. 2013). Properties and capabilities of the PLS technique have recently been criticized (McIntosh et al. 2014) because most studies in the business and economics do not evaluate the possible problems of endogeneity. Hair (2013) and his colleagues, the leading developers of PLS, have not provided any criteria on how to perform the PLS software to avoid the endogeneity. However, we propose this limitation's study as a future line of research to determine if we will have similar results applying McIntosh et al.'s (2014) suggestion to avoid the endogeneity. The authors suggest carrying out an instrumental variable estimation (IVE) that is implemented using two-stage least squares (2SLS), with the first stage involving the regression of an independent variable $x$ on an instrument $z$, followed by computing the predicted values (McIntosh et al. 2014, p. 219). Future research may tackle similar phenomena through the use of panel datasets that observe SMEs over time in other regions of Latin America, for instance, Bolivia, Ecuador, Venezuela, and Chile. Our study concerns industrial sectors, and it would be interesting to replicate the study within the service sector to determine whether similar results are obtained. As we commented in the introduction, we need to continue to learn more about the different aspects of Latin-American SMEs due to the lack of empirical studies from these countries. Finally, we would like to indicate that further studies need to be carried out to validate if the high correlation found between the collaboration of the industrial sector and human capital still gains empirical support. Our research has evaluated human capital as an independent variable. However, the results of correlation 
Peña-Vinces, JC. Casanova, L. Guillen, J. \& Urbano D (2016).International Competitiveness of Small and Medium-sized Enterprises: Peru, a Latin-American Emerging Market. Emerging Markets Finance and Trade. DOI: 10.1080/1540496X.2016.1156525 (In press).

analysis might indicate that the presence of human capital with the characteristics described above depends on industrial cooperation.

\section{REFERENCES}

Abereijo, I.O., S.A. Adegbite, M.O. Ilori, A.A. Adeniyi and H.A. Aderemi. "Technological Innovation Sources and Institutional Supports for Manufacturing Small and Medium Enterprises in Nigeria." Journal of Technology Management and Innovation 4, no. 2 (April 2009): 82-89.

Acedo, F.J. and M.V. Jones. "Speed of Internationalization and Entrepreneurial Cognition: Insights and a Comparison between International New Ventures, Exporters and Domestic Firms." Journal of World Business 42, no. 3 (September 2007): 236-252.

Antonakis, J., S. Bendahan, P. Jacquart and R. Lalive. "Causality and Endogeneity: Problems and Solutions. In D. Day (Ed.), the Oxford Handbook of Leadership and Organizations (pp. 93-117).” New York, NY: Oxford University Press. 2014.

Anwar, S.T. "Vodafone and the Wireless Industry: A Case in Market Expansion and Global Strategy." Journal of Business and Industrial Marketing 18, no. 3 (2003): 270-288.

Aragón-Correa, J.A., N. Hurtado-Torres, S. Sharma and V.J. García-Morales. "Environmental Strategy and Performance in Small Firms: A Resource-Based Perspective.” Journal of Environmental Management 86, no. 1 (January 2008): 88-103.

Arze, E.C. and B. Svensson. 'Development of International Competitiveness in Industries and Individual Firms in Developing Countries: The Case of the Chilean Forest-Based Industry and the Chilean Engineering Firm Arze, Recin and Asociados." International Journal of Production Economics 52, no. 1-2 (October 1997): 185-202.

Banerjee, S. "Determinants of International Competitiveness: A Comparative Study of the Sugar Industry in Australia, Brazil, and the European Union". Masters by Research thesis, Queensland University of Technology, 2005.

Barge-Gil, A. and A. Modrego. "The Impact of Research and Technology Organizations on Firm Competitiveness. Measurement and Determinants.” The Journal of Technology Transfer 36, no. 1 (February 2011): 61-83.

Belso-Martínez, J.A. "Why are Some Spanish Manufacturing Firms Internationalizing Rapidly? The Role of Business, and Institutional International Networks.” Entrepreneurship and Regional Development 18, no. 3 (February 2006): 207-226.

Birru, W.T. "Horizontal Inter-Firm Cooperation in Ethiopian Small and Medium Enterprises: Evidence from Leather Shoe Manufacturing Firms in Addis Ababa.” Journal of Small Business and Enterprise Development, 18, no. 4 (2011): 806820.

Bloomberg. Best Emerging Markets 2014. http://www.bloomberg.com/visual-data/best-and-worst//best-emerging-markets2014-countries.

Bonaccorsi, A. "On the Relationship between Firm Size and Export Intensity.” Journal of International Business Studies 23, no. 4 (1992): 605-635.

Buckley, P.J., C.L. Pass and K. Prescott. "Measure of International Competitiveness: Empirical Findings from British Manufacturing Companies.” Journal of Marketing Management 6, no. 1 (May 1990): 1-13.

Buysse, D. J., C. F. III. Reynolds, T. H Monk, S.R. Berman, and D.J. Kupfer. “The Pittsburgh Sleep Quality Index: A new Instrument for Psychiatric Practice and Research.” Psychiatry Research 28, no. 2 (May 1989), 193-213.

Casanova, L.S. Global Latinas: Latin America’s Emerging Multinationals. London: Palgrave Macmillan, 2009.

Casanova, L.S. and J. Kassum. The Political Economy of an Emerging Global Power: In Search of the Brazil Dream. London: Palgrave Macmillan, 2014.

Castro-Gonzáles, S., J.C. Peña-Vinces and J. Guillen. "The Competitiveness of Latin-American Economies: Consolidation of 
Peña-Vinces, JC. Casanova, L. Guillen, J. \& Urbano D (2016).International Competitiveness of Small and Medium-sized Enterprises: Peru, a Latin-American Emerging Market. Emerging Markets Finance and Trade. DOI: 10.1080/1540496X.2016.1156525 (In press).

the Double-Diamond Theory." Economic System 4, no. 4 (December 2006): In press.

Cerrato, D. and D. Depperu. 'Unbundling the Construct of Firm-Level International Competitiveness.” Multinational Business Review 19, no. 4 (2011): 311-331.

Chang, S., A. Witteloostuijn and L. Eden. "From the Editors: Common Method Variance in International Business

Research.” Journal of International Business Studies 41, no. 2, (2010):178-184.

Chen, Y.M. and F.J. Lin. "Regional Development and Sources of Superior Performance across Textile and IT Sectors in Taiwan.” Entrepreneurship and Regional Development 18, no. 3 (May 2006): 227-248.

Cheng-Hua, T. "An Evolutionary-Institutional Framework for the Growth of an Indigenous Technology Firms: The Case of Lenovo Computer.” Technology in Society 33, no. 3-4(August-November 2011): 212-222.

Chin, W.W. "Issues and Opinion on Structural Equation Modeling.” MIS Quarterly 22, no. 1 (March 1998): 7-21.

Chin, W.W. and T. Frye. PLS-Graph: Version 3.00 Build 1016. The University of Houston. (1998).

Cho, J.Y, C.S. Leem and K.T. Shin. "The Relationships among Manufacturing Innovation, Competitiveness, and Business

Performance in the Manufacturing Industries of Korea.” The International Journal of Advanced Manufacturing Technology 38, no. 7-8 (June 2007): 840-850.

Coviello, N.E., N.G. Pervez and K.H.A. Martin. 'International Competitiveness: Empirical Findings from SME Service Firms.” Journal of International Marketing 6, no. 2 (1998): 8-27.

Cuervo-Cazurra, A. "The Multinationalization of Developing Country MNEs: the Case of Multilatinas.” Journal of International Management 14, no. 2 (June 2008): 138-154.

Cuervo-Cazurra, A., P. Martin de Holan and L. Sanz. 'Location Advantages: Emergent and Guided Co-evolutions." Journal of Business Research 67, no. 4 (April 2014): 508-515.

D’Cruz, J.R. and A.M. Rugman. 'Developing International Competitiveness: The Five Partners.” Business Quarterly 58 (Winter 1993): 60-72.

Díaz, J.J. Formalizacion empresarial y laboral [Business and labor formalization] In Infante and Chacaltana (Eds.). Hacia un desarrollo inclusivo el caso del Perú [Towards inclusive development for Peru] United Nations, Santiago de Chile (Chapter III), 2014.

Doty, D. H. and W. H. Glick. "Common Methods Bias: Does Common Methods Variance Really Bias Results?." Organizational Research Methods 1, no. 4 (October 1998): 374- 406.

Elenurm, T. 'International Competitiveness and Organizational Change Drivers Anticipated by Estonian Managers in the Context of European Integration.” Baltic Journal of Management 2, no. 3 (2007): 305-318.

European Commission. The new SME Definition. User guide and model declaration. Enterprise and Industry PublicationsEuropean Commission, 2005.

Fahy, J. “A Resource-Based Analysis of Sustainable Competitive Advantage in a Global Environment.” International Business Review 11, no. 1 (February 2002): 57-77.

Ferrier, F. "Navigating the Competitive Landscape the Driver and Consequences of Competitive Aggressiveness." Academy of Management Journal 44, no. 4 (August 2001): 858-877.

Filatotchev, C., N. Isachenkova and T. Mickiewicz. “Corporate Governance, Managers' Independence, Exporting, and Performance of Firms in Transition Economies.” Emerging Markets Finance and Trade 43, no. 5 (December 2007): 6267.

Galán, J.I., J. González-Benito and J.A. Zuñiga-Vincente. "Factors Determining the Location Decisions of Spanish MNEs: An Analysis Based on the Investment Development Path.” Journal of International Business Studies 38 (November 
Peña-Vinces, JC. Casanova, L. Guillen, J. \& Urbano D (2016).International Competitiveness of Small and Medium-sized Enterprises: Peru, a Latin-American Emerging Market. Emerging Markets Finance and Trade. DOI: 10.1080/1540496X.2016.1156525 (In press).

2007): 975-997.

Guerrieri, P. and C. Pietrobelli. 'Industrial Districts' Evolution and Technological Regimes: Italy and Taiwan.” Technovation 24, no. 11 (November 2004): 899-914.

Hair, J.F., M. Sarstedt, C.M. Ringle and J.A. Mena. "An Assessment of the Use of Partial Least Squares Structural Equation Modeling in Marketing Research.” Journal of the Academy of Marketing Science 40, no. 3 (June 2011): 414- 433.

Hair, J.F., G.T.M. Hult, C.M. Ringle and M.A. Sarstedt. A Primer on Partial Least Squares Structural Equation Modeling (PLS-SEM). Thousand Oaks: Sage, 2013.

Hatch, N. and J. Dyer. 'Human Capital and Learning as a Source of Sustainable Competitive Advantage." Strategic Management Journal 25, no. 12 (October 2004): 1155-1178.

Haynes, S. N., D. C. S. Richard and E. S. Kubany. "Content Validity in Psychological Assessment: A Functional Approach to Concepts and Methods.” Psychological Assessment 7 no. 3 (September 1995): 238-247.

Hitt, M.A., L. Tihanyi, T. Miller and B. Connelly. "International Diversification: Antecedents, Outcomes, and Moderators". Journal of Management 32, no. 6 (December 2006): 831-867.

Hofstede, G. "Cultural Constraints in Management Theories." Academy of Management Executive 1, no. 1 (February 1993): 81-94.

Inter-American Development Bank. Industrial Production: Real Index, 2010. Download at:

http://data.iadb.org/ViewIndicator/ViewIndicator?languageId=en\&typeOfUrl=C\&indicatorId=352.

Inter-American Development Bank. Exports of Goods (BOP): \% of GDP, 2015. Download at: http://data.iadb.org/ViewIndicator/ViewIndicator?languageId=en\&typeOfUrl=C\&indicatorId=362.

Ito, K., and V. Pucik. "R\&D Spending, Domestic Competition and Export Performance of Japanese.” Strategic Management Journal 14, no. 1(January 1993): 61-75.

Jin, B. and H.C. Moon. 'The Diamond Approach to the Competitiveness of Korea's Apparel Industry: Michael Porter and Beyond.” Journal of Fashion Marketing and Management 10, no. 2 (2006): 195-208.

Kamakura, W.A. “Common Methods Bias”. Wiley International Encyclopedia of Marketing. 2010.

Kasahara, S. The Flying Geese Paradigm: A Critical Study of its Application to East Asian Regional Development; Discussion Papers, UNCTAD, 2004.

Knight, G.A. and D. Kim. 'International Business Competence and the Contemporary Firm.” Journal International Business Studies 40 (February/March 2009): 225-273.

Leonidou, L.C., C.S. Katsikeas and N.F. Piercy. "Identifying Managerial Influences on Exporting: Past Research and Future Directions.” Journal of International Marketing 6, no. 2 (1998): 74-103.

Lin, K.H. and I. Chaney. "The Influence of Domestic Interfirm Networks on the Internationalization Process of Taiwanese SMEs." Asia Pacific Business Review 13, no. 4 (September 2007): 565-583.

Marcoulides, G.A. and C. Saunders. “PLS: A Silver Bullet?” MIS Quarterly 30, no. 2 (June 2006): 3-9.

McIntosh, C. N., J. R. Edwards and J. Antonakis. Reflections on Partial Least Squares Path Modeling. Organizational Research Methods 17, no. 2 (April 2014): 210-251.

Mesquita, L.F. and S.G. Lazzarini. 'Horizontal and Vertical Relationships in Developing Economies: Implications for SMEs' Access to Global Markets.” Academy of Management Journal 51, no. 2 (April 2008): 359-380.

Mincetur. Peruvian's Ministry of Tourism and Commerce, http://www.mincetur.gob.pe/newweb (May 6, 2006).

Moen, O. and P. Servais. "Born Global or Gradual Global Examining the Export Behavior of Small And Medium-Sized Enterprises." Journal of International Marketing 10, no. 3 (2002): 49-72. 
Peña-Vinces, JC. Casanova, L. Guillen, J. \& Urbano D (2016).International Competitiveness of Small and Medium-sized Enterprises: Peru, a Latin-American Emerging Market. Emerging Markets Finance and Trade. DOI: 10.1080/1540496X.2016.1156525 (In press).

Moon, H.C., and D. Lee. "The Competitiveness of Multinational Firms: A Case Study of Samsung Electronics and Sony." Journal of International and Area Studies 11, no. 1 (June 2004): 1-21.

Nadvi, K. "Collective Efficiency and Collective Failure: The Response of the Sialkot Surgical Instrument Cluster to Global Quality Pressures.” World Development 27, no. 9 (September 1999): 1605-1626.

Nunnally, J. Psychometric Theory (third edition). New York: McGraw-Hill, 1997.

Oviatt, B. and P. McDougall. “Toward a Theory of International New Ventures.” Journal of International Business Studies 25, no. 1 (1994): 45-64.

Peña-Vinces, J.C. "Comparative Analysis of Competitiveness on the Peruvian and Chilean Economies from a Global View." Journal of Economics, Finance and Administrative Science 14, nº 27 (2009): 87-105.

Peña-Vinces, J.C. and B.L. Delgado-Márquez. "Are Entrepreneurial Foreign Activities of Peruvian SMNEs Influenced by International Certifications, Corporate Social Responsibility and Green Management?” International Entrepreneurship Management Journal 9, no. 4 (December 2013): 603-618.

Peña-Vinces, J.C. and D. Urbano. "The Influence of Domestic Economic Agents on the International Competitiveness of Latin American Firms: Evidence from Peruvian Small and Medium Multinational Enterprises." Emerging Markets Finance and Trade, 50, no. 6 (April 2014): 43-63.

Peña-Vinces, J.C, G.A. Cepeda and W.W. Chin. "Effect of ITC on the International Competitiveness of Firms." Management Decision 50, no. 6 (2012): 1045-1061.

Pla-Barber, J. "The Internalization of Foreign Distribution and Production Activities: New Empirical Evidence from Spain." International Business Review 10, no. 4 (August 2001): 455-474.

Podsakoff, P.M. and D.W. Organ. "Self-Reports in Organizational Research: Problems and Prospects. ”Journal of Management 12, no. 4 (Winter 1986): 531-544.

Podsakoff, P.M. MacKenzie, S.B. Lee, J.Y. and Podsakoff, N.P. "Common Method Biases in Behavioral Research: A Critical Review of the Literature and Recommended Remedies." Journal of Applied Psychology 88, no. 5(October 2003): 879-903.

Porter, M.E. The Competitive Advantage of Nations. Boston, MA, USA: The Free Press, 1990.

Porter, M.E. On Competition. Boston, M.A.: Harvard Business School, 1998.

Roberts, N. and J. Thatcher. "Conceptualizing and Testing Formative Constructs: Tutorial and Annotated Example." The Data Base for Advances in Information Systems 40, no. 3 (August 2009): 9-39.

Rialp A., J. Rialp and G.A. Knight. 'The Phenomenon of Early Internationalizing Firms: What Do We Know after a Decade (1993-2003) of Scientific Inquiry?’ International Business Review 14, no. 2 (April 2005):147-166.

Rugman, A.M. and A. Verbeke. Global Corporate Strategy and Trade Policy. London/New York: Croom Helm/Routledge, 1990.

Sánchez-Chiappe, I. and A.P. Poratelli. "The World Economic Forum Report, Value Chains and the Creation of Wealth in Latin American Countries.” International Business: Research, Teaching and Practice 1 (2011): 41-55.

Semadeni, M., M.C. Withers and S.T. Certo. "The Perils of Endogeneity and Instrumental Variables in Strategy Research:

Understanding through Simulations.” Strategic Management Journal, 35, no. 7 (Jun 2013): 1070-1079.

Subhash, J. "Standardization of International Marketing Strategy: Some Research Hypotheses.” Journal of Marketing 53, no. 1 (January 1989): 70-79.

Triguero-Sánchez, R., J.C. Peña-Vinces, J. Guillen and M. Sánchez-Apellániz. “Human Capital-Demographic Diversity in the Relationship between HRM Practices and Firm Performance: The Spanish Case." International Business 
Peña-Vinces, JC. Casanova, L. Guillen, J. \& Urbano D (2016).International Competitiveness of Small and Medium-sized Enterprises: Peru, a Latin-American Emerging Market. Emerging Markets Finance and Trade. DOI: 10.1080/1540496X.2016.1156525 (In press).

Management 10, no. 3 (2016): 277-291.

Theodosiou, M. and L.C. Leonidou. "Standardization versus Adaptation of International Marketing Strategy: An Integrative Assessment of the Empirical Research.” International Business Review 12, no. 2 (April 2003): 141-171.

Toppinen, A., R. Toivonen, A. Mutanen, A. Goltsev and A. Tatti. "Sources of Competitive Advantage in Woodworking

Firms of Northwest Russia." International Journal of Emerging Markets 2, no. 4 (2007): 383-394.

Wheeler, C., K. Ibeh and P. Dimitratos. 'UK, Export Performance Research: Review and Implications.” International Small

Business Journal 26, no. 2 (April 2008): 207- 239.

World Bank. Latin America and Caribbean Results, 2015. Download at: http://www.worldbank.org/

Wu, J. and N. Pangarkar. 'Rising to the Global Challenge: Strategies for Firms in Emerging Markets." Long Range Planning 39, no. 3 (June 2006): 295-313.

Yuhua, Z. and A. Bayhaqi. SMEs'Participation in Global Production Chains. Asia-Pacific Economic Cooperation Secretariat 35 Heng Mui Keng Terrace, 2013.

Zeng, S.X., X.M. Xie, C.M. Tam and T.W. Wan. "Competitive Priorities of Manufacturing Firms for Internationalization: An Empirical Research.” Measuring Business Excellence 12, no 3 (2008): 44-45.

Zou, S. and S. Stan. "The Determinants of Export Performance: A Review of the Empirical Literature between 1987 and 1997." International Marketing Review 15, no. 5 (1998): 333-356.

Zou, S., D.M. Andrus and D.W. Norvell. "Standardization of International Marketing Strategy by Firms from a Developing Country." International Marketing Review 14, no. 2 (1997): 107-123. 
Peña-Vinces, JC. Casanova, L. Guillen, J. \& Urbano D (2016).International Competitiveness of Small and Medium-sized Enterprises: Peru, a Latin-American Emerging Market. Emerging Markets Finance and Trade. DOI: 10.1080/1540496X.2016.1156525 (In press).

\section{TABLES}

Table 1: Sample characteristics

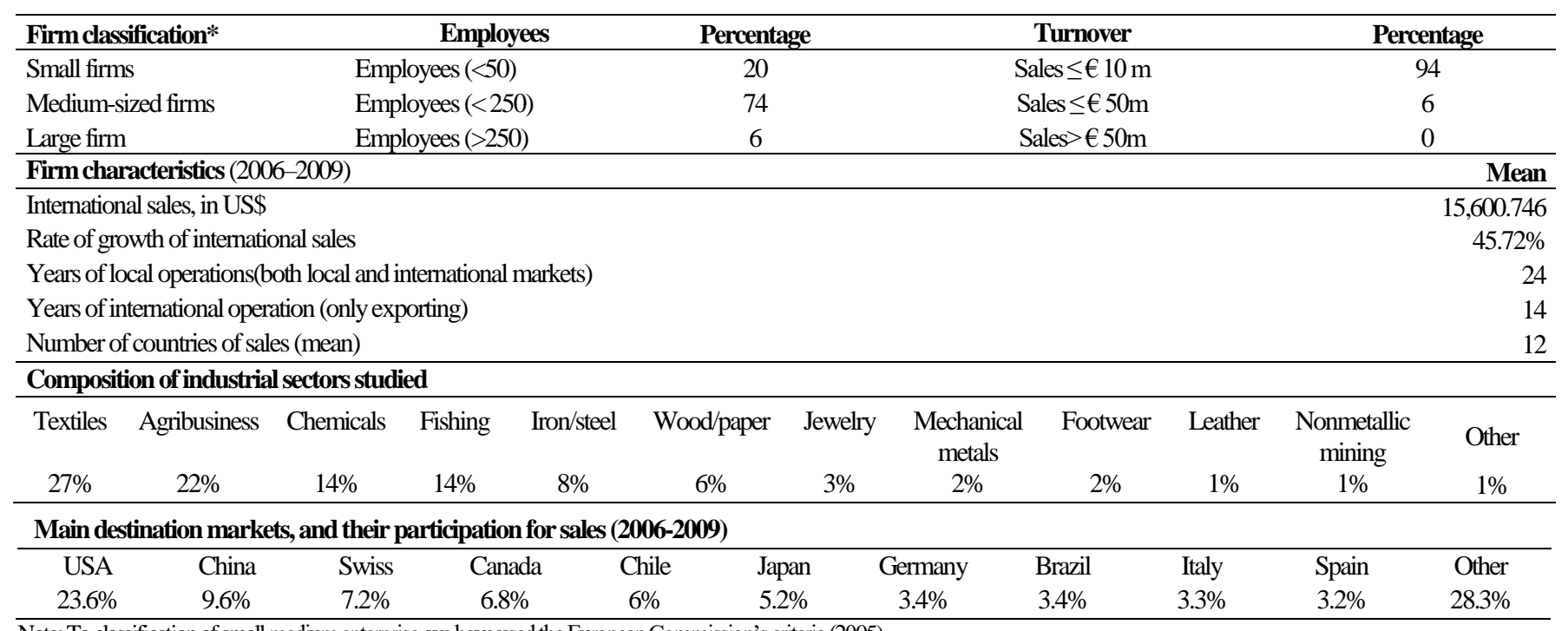

Note: To classification of small medium enterprise, we have used the European Commission's criteria (2005)

Table 2: Results of the measurement model and exploratory principal components analysis

\begin{tabular}{|c|c|c|c|c|c|c|}
\hline REFLECTIVE CONSTRUCTS & KMO & $\chi^{2}$ & $\mathbf{C R}$ & AVE & Loading & Weight \\
\hline The Environment of Host Country ( $1=$ not at all important, $7=$ highly important) & 0.724 & $121.662 * * *$ & 0.898 & 0.596 & & \\
\hline Large size of host markets & & & & & 0.8652 & 0.4141 \\
\hline Growth of demand in the host markets (potential growth) & & & & & 0.7554 & 0.1352 \\
\hline Low levels of competition in the host markets & & & & & 0.7336 & 0.1671 \\
\hline Incentives of tax reduction measures in the host market & & & & & 0.7467 & 0.1419 \\
\hline Tax cut incentives in the country of origin & & & & & 0.7429 & 0.2824 \\
\hline Demographic similarities of customers and foreign consumers (race, religion, habits, etc.). & & & & & 0.7663 & 0.1322 \\
\hline FIRMAGE & n.a & n.a & 0.766 & 0.641 & & \\
\hline Local age of firms (Number of years functioning in the local markets of country of origin) & & & & & 0.5104 & 0.0423 \\
\hline Intemational age of firms (Number of years exporting) & & & & & 0.9993 & 0.9794 \\
\hline Global Strategy $(1=$ strongly disagree, 7 = strongly agree $)$ & 0.842 & $754.415^{* * * *}$ & 0.841 & 0.657 & & \\
\hline The needs of our customers are standardized worldwide & & & & & 0.5765 & 0.1301 \\
\hline Ourproducts/services are known worldwide & & & & & 0.9428 & 0.6695 \\
\hline Our technology is standardized worldwide & & & & & 0.8652 & 0.3395 \\
\hline We encounter the same competitors in most markets & & & & & $\ldots$ & \\
\hline Our marketing policies can be standardized worldwide & & & & & - & \\
\hline \multicolumn{7}{|l|}{ Collaboration of Industrial Sectors (Second-order common latent construct) } \\
\hline $\begin{array}{l}\text { SECTOR COOPERATION }\left(\mathrm{y}_{1}\right) \text { (First-order common latent construct) } \\
\text { (1=not at all important, } 7=\text { highly important) }\end{array}$ & 0.618 & $251.660 * * * *$ & 0.803 & 0.579 & & \\
\hline Intemational client's relevance & & & & & - & \\
\hline Relationship with client's relevance in internationalization & & & & & $\ldots$ & \\
\hline Presence of suppliers abroad & & & & & 0.8826 & 0.5360 \\
\hline Relationship with supplier's relevance in internationalization & & & & & 0.7195 & 0.3444 \\
\hline Presence of competitors in the intemational environment & & & & & - & \\
\hline Relationship with competitor's relevance in internationalization & & & & & 0.6676 & 0.4228 \\
\hline$N E T W O R K I N G\left(\mathrm{Y}_{2}\right)$ (First-order common latent construct) & 0.500 & $19.830 * * * * *$ & 0.832 & 0.712 & & \\
\hline $\begin{array}{l}\text {-The decisions of internationalization of the company are generally al ways made based on industry } \\
\text { experience and knowledge derived from other companies in the sector ( } 1=\text { never, } 7=\text { always) }\end{array}$ & & & & & 0.8068 & 0.5262 \\
\hline -Leaming among business groups and membership of a network can help to reduce the risk and & & & & & 0.8798 & 0.6541 \\
\hline
\end{tabular}


Peña-Vinces, JC. Casanova, L. Guillen, J. \& Urbano D (2016).International Competitiveness of Small and Medium-sized Enterprises: Peru, a Latin-American Emerging Market. Emerging Markets Finance and Trade. DOI: 10.1080/1540496X.2016.1156525 (In press).

\begin{tabular}{|c|c|c|c|c|c|c|}
\hline \multicolumn{7}{|l|}{$\begin{array}{l}\text { uncertainty of going out and competing for foreign markets without having to wait to know and dominate } \\
\text { their own market (local market). (1= never, } 7=\text { always) }\end{array}$} \\
\hline FirmSize & n.a & n.a & & & & \\
\hline Number of employees of firms during the last three years & & & 1 & 1 & 1 & 1 \\
\hline \multicolumn{7}{|l|}{ FORMATIVE CONSTRUCTS } \\
\hline \multicolumn{3}{|l|}{ Firm's International Competitiveness (First-order common latent construct) } & VIF & Weight & Loading & T-Statistic \\
\hline \multicolumn{3}{|l|}{-Approximate average percentage of net profits achieved during the last three years } & 1.119 & 0.1726 & 0.1783 & 1.6960 \\
\hline \multicolumn{3}{|c|}{-Approximate average percentage of net profits achieved during the last three years as a consequence of overseas sales (exporting) } & 1.172 & 0.1783 & 0.9643 & 7.3087 \\
\hline \multicolumn{3}{|c|}{$\begin{array}{l}\text {-Assess the success of the company in foreign countries during the last three years } \\
(1=\text { very poor, } 5-10 \% ; 2=\text { poor, } 10-20 \% ; 3=\text { average, } 20-40 \% ; 5=\text { very good, } 80-100 \% \text {.) }\end{array}$} & 2.311 & 0.9643 & -0.0165 & 3.2713 \\
\hline \multicolumn{3}{|l|}{$\begin{array}{l}\text {-Satisfaction of compliance with objectives and goals achieved in foreign markets in the last three years } \\
(1=\text { very poor, } 5-10 \% ; 2=\text { poor, } 10-20 \% ; 3=\text { average, } 20-40 \% ; 5=\text { very good, } 80-100 \% \text {.) }\end{array}$} & 2.292 & -0.0165 & 0.1726 & 1.2903 \\
\hline \multicolumn{3}{|l|}{ Human Capital (First-order common latent construct) } & VIF & Weight & Loading & T-Statistic \\
\hline \multicolumn{3}{|l|}{ Age of employees } & 1.389 & -0.3436 & -0.4573 & 2.1570 \\
\hline \multicolumn{3}{|l|}{ Level of education (BA, MA, $\mathrm{PhD})$ and experience } & 1.722 & 0.1784 & 0.4793 & 2.3647 \\
\hline \multicolumn{3}{|l|}{ Fluency in foreign languages } & 1.521 & 0.0755 & 0.3535 & 1.2655 \\
\hline \multicolumn{3}{|l|}{ Knowledge of foreign markets } & 2.532 & 0.4961 & 0.8147 & 7.0642 \\
\hline \multicolumn{3}{|l|}{ Experience of other countries and cultures } & 1.272 & 0.0943 & 0.4364 & 1.6169 \\
\hline \multicolumn{3}{|l|}{ English as a means to work in the firm } & 1.917 & 0.4990 & 0.5719 & 2.6110 \\
\hline
\end{tabular}

Note: Kaiser-Meyer-Olkin; భ2: Bartlett's test of sphericity; VIF: Variance inflation factor; CR: Composite reliability; AVE: Average variance extracted; n.a: not applicable

Table 3: Discriminant validity coefficients and descriptive statistics of PLS-SEM

\begin{tabular}{|c|c|c|c|c|c|c|c|c|c|c|}
\hline & $\mathrm{N}$ & Mean & SD & (1) & (2) & (3) & (4) & (5) & (6) & (7) \\
\hline (1) Firm's international competitiveness & 100 & 3.177 & 1.291 & N.A. & & & & & & \\
\hline (2) Global strategy & 100 & 4.512 & 1.946 & 0.518 & 0.812 & & & & & \\
\hline (3) Collaboration of industrial sector & 100 & 5.865 & 1.692 & 0.540 & 0.377 & 0.792 & & & & \\
\hline (4) Human capital & 100 & 4.531 & 1.582 & 0.304 & 0.392 & 0.331 & 0.257 & N.A. & & \\
\hline (5) Environment of host country & 100 & 4.636 & 1.492 & 0.212 & 0.318 & 0.168 & 0.098 & 0.291 & 0.772 & \\
\hline (6) Firm size & 100 & 1.000 & 1.000 & 0.147 & 0.247 & 0.090 & 0.258 & 0.035 & 0.126 & N.A. \\
\hline (7) Firm age & 100 & 0.164 & 0.406 & -0.186 & 0.097 & -0.022 & 0.212 & -0.073 & -0.088 & 0.391 \\
\hline
\end{tabular}

Notes: N: number of firms, SD: standard deviation, Diagonal elements (italicized) are the square root of variance shared between constructs and their measures (AVE). Off-diagonal elements are correlations among constructs. For discriminant validity, diagonal elements should be larger than off-diagonal elements; N.A. - not applicable,

Table 4: Structural model results

\begin{tabular}{lccc}
\hline \multicolumn{1}{c}{ Hypothesis } & Path coefficients & T-values & Support \\
\hline H1: Global strategy $\rightarrow$ Firm's international competitiveness & $0.364^{* *}$ & 2.7831 & Yes \\
H2: Human capital $\rightarrow$ Firm's international competitiveness & $0.012^{(\mathrm{ns})}$ & 0.1057 & No \\
H3: Human capital $\rightarrow$ Global strategy & $0.247^{*}$ & 2.0059 & Yes \\
H4: Firm size $\rightarrow$ Firm's international competitiveness & $0.124^{(\mathrm{ns})}$ & 1.3188 & No \\
H5: Firm age $\rightarrow$ Firm's international competitiveness & $-0.261^{(\mathrm{ns})}$ & -1.3787 & No \\
H6: Collaboration of industrial sector $\rightarrow$ Firm's international competitiveness & $0.382^{* *}$ & 2.8337 & Yes \\
H7: Collaboration of industrial sector $\rightarrow$ Global strategy & $0.261^{* *}$ & 2.2887 & Yes \\
H8: Environment of host country $\rightarrow$ Global strategy & $0.202^{*}$ & 2.0519 & Yes \\
\hline
\end{tabular}

*p < 0.05 (based on $\mathrm{t}$ (4999), one-tailed test; $t$-values are: 1.6451585), **p < 0.01(based on $\mathrm{t}$ (4999), one-tailed test; $t$-values are 2.32709405) ns: Not significant 
Peña-Vinces, JC. Casanova, L. Guillen, J. \& Urbano D (2016).International Competitiveness of Small and Medium-sized Enterprises: Peru, a Latin-American Emerging Market. Emerging Markets Finance and Trade. DOI: 10.1080/1540496X.2016.1156525 (In press).

Figure 1: Research model

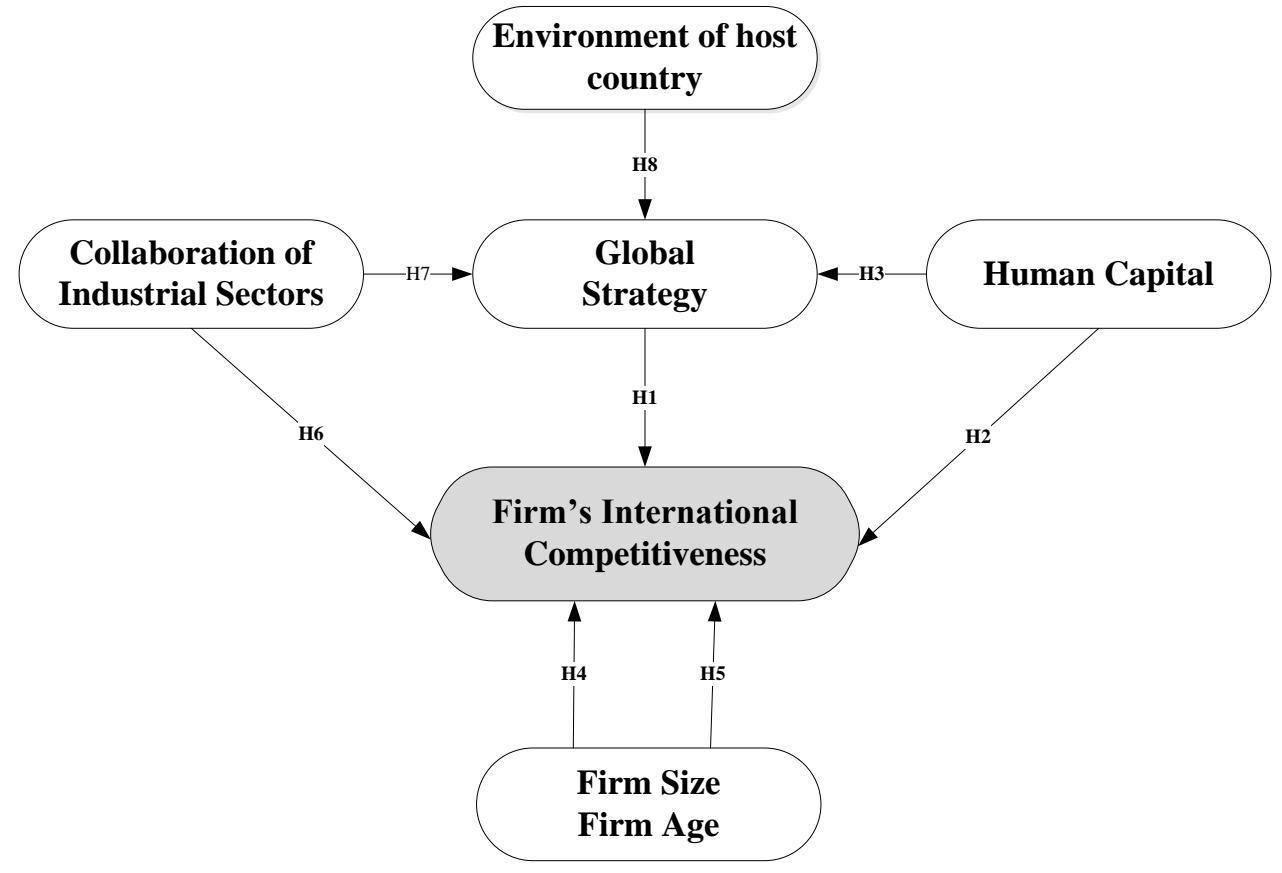

Figure 2: Results of PLS-SEM

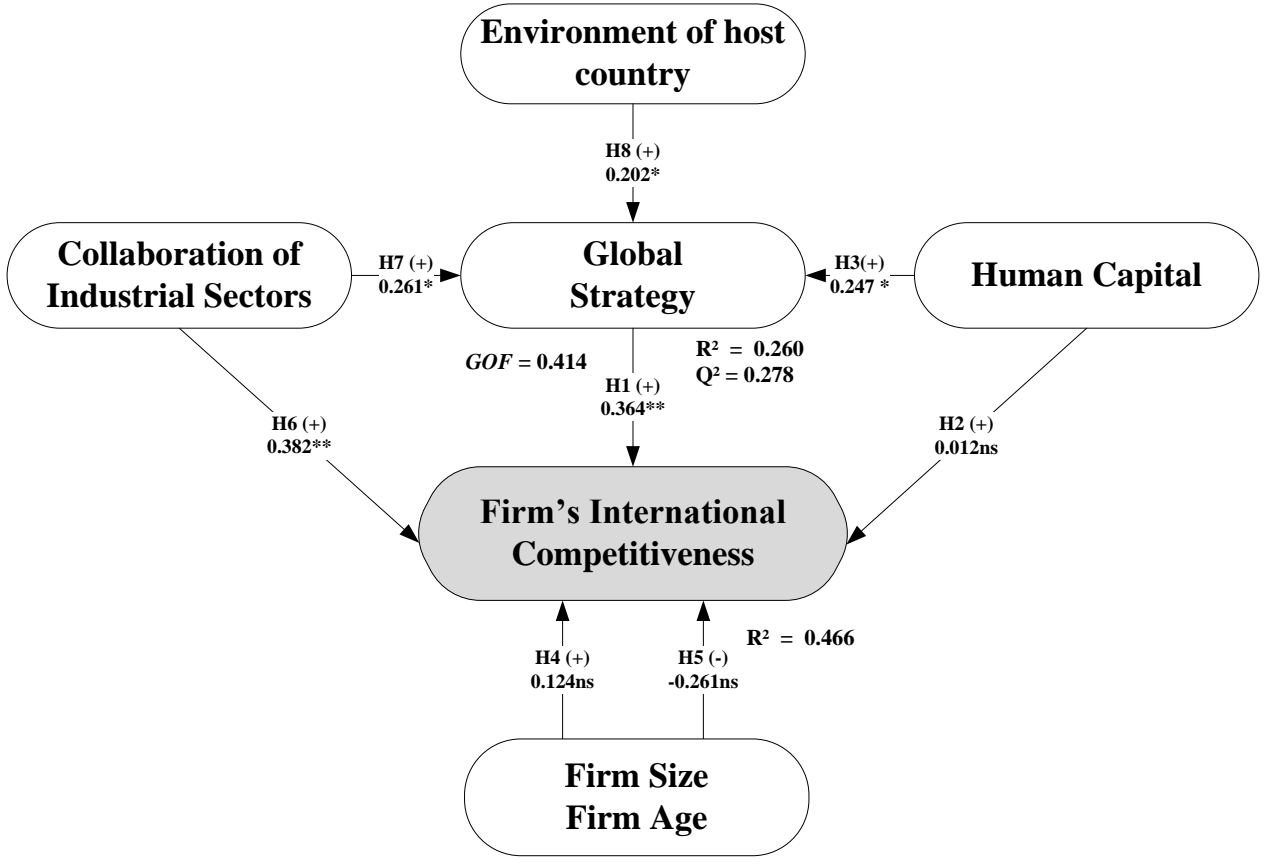

Note: $* \mathrm{p}<.05 ; * * \mathrm{p}<.01$; (based on a Student $\mathrm{T}_{(4999)}$ distribution with one tail), ns: Not significant 
Peña-Vinces, JC. Casanova, L. Guillen, J. \& Urbano D (2016).International Competitiveness of Small and Medium-sized Enterprises: Peru, a Latin-American Emerging Market. Emerging Markets Finance and Trade. DOI: 10.1080/1540496X.2016.1156525 (In press). 